\title{
Moderating influence of school culture on the relationship between transformational leadership and organizational health of secondary school teachers in Malaysia
}

\author{
Anantha Raj A. Arokiasamy \\ Xiamen University Malaysia, \\ Persiaran Sunsuria, Bandar Sunsuria, 43900 Sepang, Selangor, Malaysia \\ Dr, School of Economics and Management
}

\section{open 2 access (c) dol}

Article history:

Received: March, 2017

1st Revision: April, 2017

Accepted: April, 2017

\section{JEL classification:}

H75

M14

\section{DOI:}

10.14254/jems.2017.2-1.2

\begin{abstract}
This study aimed to determine the level of transformational leadership practices by school principals in the national secondary schools in the state of Pulau Pinang and Kedah Darul Aman, Malaysia. The three dimensions of transformational leadership studied were vision identification, intellectual stimulation and high performance expectations. The study also looks at the level of organizational health as well as the relationship with the practice of transformational leadership by the national secondary school principals'. The respondents consisted of 226 teachers employed in 16 national secondary schools in the state of Pulau Pinang and Kedah Darul Aman, Malaysia. The data obtained was analyzed using SPSS version 20.0. Descriptive analysis and inferential analysis were used to analyze the influence of the relationship. The study found that school culture functions as a moderator in the relationship between the transformational leadership style of school principals' and the organizational health of the secondary school teachers' in the state of Pulau Pinang and Kedah Darul Aman, Malaysia. In addition, school culture as a moderator in the relationship between transformational leadership and organizational health is a new discovery in the field of leadership. This is because the organizational health of secondary schools has never been investigated by local researchers. Most previous studies have highlighted transformational leadership and school culture has a direct influence on school improvement.
\end{abstract}

Keywords: transformational leadership style, school culture, organizational health, job satisfaction, school principals. 


\section{Introduction}

There is great interest in educational leadership in the early part of the 21st century. This is because of the widespread belief that the quality of leadership makes a significant difference to school and student outcomes. In many parts of the world, including both developed and developing countries, there is recognition that schools require effective leaders and managers if they are to provide the best possible education for their students and learners. As the global economy gathers pace, more governments are realizing that their main assets are their people and that remaining or becoming, competitive depends increasingly on the development of a highly skilled workforce. This requires trained and committed teachers but they, in turn; need the leadership of highly effective principals with the support of other senior and middle managers (Cemaloglu et al., 2012).

Transformational Leadership moves individuals toward a level of commitment to achieve school goals by identifying and articulating a school vision, fostering the acceptance of group goals, providing individualized support, providing intellectual stimulation, providing an appropriate model and having high performance expectations (Jantzi \& Leithwood, 1996). For this study, transformational leadership will mean the manner in which the school principal guide and encourage fellow staff to work, communicate the schools' goal and empower them to achieve the schools' vision.

- The independent variable; transformational leadership in this study measures three dimensions as follows:

Vision identification: this factor relates to principal behaviors that are aimed at identifying new opportunities for staff members and developing, articulating and inspiring others with his or her vision for the future (Jantzi \& Leithwood, 1996).

Intellectual Stimulation: principal behaviors that challenge staff members to reexamine some of their assumptions about their work and to reconceive ways to do it are representative of this factor (Jantzi \& Leithwood, 1996).

High Performance Expectations: this factor involves behaviors that demonstrate the principal's expectations for excellence, quality and high performance on the part of the staff (Jantzi \& Leithwood, 1996). follows:

- The moderating variable, school culture in this study measures three dimensions as

Teacher Collaboration: describes the degree to which teachers engage in constructive dialogue that furthers the educational vision of the school. Teachers across the school plan together, observe and discuss teaching practices, evaluate programs and develop an awareness of the practices and programs of other teachers (Gruenert, 1998).

Unity of Purpose: describes the degree to which teachers work toward a common mission for the school. Teachers understand, support and perform in accordance with that mission (Gruenert, 1998).

Collegial Support: describes the degree to which teachers work together effectively. Teachers trust each other, value each other's ideas and assist each other as they work to accomplish the tasks of the school organization (Gruenert, 1998).

- The dependent variable, organizational health in this study measures three dimensions as follows:

Institutional integrity: As an institutional-level health indicator, institutional integrity was described by Hoy and Woolfolk (1993) as the school's level of ability to protect faculty members from any outside forces. Institutional integrity was one of the two out of the seven health dimensions to actually predict general personal efficacy of teachers. Institutional integrity represented a major predictor of the faculty members' trust in the school principal. Hoy also discovered teachers to be more committed to schools with a high institutional integrity.

Consideration: another administration-level dimension of health (Hoy \& Woolfolk, 1993), was deemed as high when principal behavior was proved collegial and supportive (Hoy et al., 1991). In other words, the principal's friendliness in a healthy school did not preclude high standards. Hoy found consideration to be a predictor of trust for faculty members - trust in their principal and in their colleagues, as well. Consideration has been linked to ethical leadership. Brown, Trevino and Harrison (2005) found a positive correlation between ethical leadership and consideration. When leaders demonstrated high levels of consideration, followers performed higher quality work, appeared more satisfied, and perceived the leader as more effective (Yukl, 2002). Leaders with high consideration scores were found by Fleishman and Harris to have (1962) experienced fewer turnovers, obtained higher job satisfaction from workers and received a lower number of grievances filed. However, that same study did show performance levels of the workers to be lower as well. According to Hoy and Woolfolk (1993), principals exemplifying C were found to have stronger systems of management. 
Principal Influence: Hoy and Woolfolk (1993) considered principal influence an administrative-level dimension of organizational health. Hoy et al. (1991) defined principal influence as the principal's ability to sway the school board and director. Principal influence accompanied by Morale could together predict collegial mutual trust. In Styron's and Nyman's (2008) study, influence of the principal was significantly different among high and low performing middle schools. High performing middle schools scored a lower principal influence rating than did low performing middle schools.

Although this model served the educational field for the past two decades, the current demands for educational reform have forced many school leaders to reevaluate and adapt their leadership style to meet current demands. Many educational leaders are beginning to embrace and put into practice a school model of transformational leadership. This leadership model is espoused by school leaders because it "aspires, more generally, to increase members' efforts on behalf of the organization, as well as to develop more skilled practice" (Leithwood, Jantzi, \& Steinbach, 1999). There is compelling evidence that transformational leadership behaviors, significantly affect teachers' psychological states, such as, teaching efficacy, job satisfaction, and organizational commitment (Bass \& Riggo, 2006; Leithwood, Jantzi, et al., 1999). Furthermore, a review of school leadership research reveals that school leaders who demonstrate transformational leadership behaviors have staffs who report higher levels of job satisfaction (Bogler, 2001; Griffith, 2004; Arokiasamy et al., 2015)), which is consistent with Bass and Riggo's (2006) claim.

\section{Problem Statement}

According to Zaidatol Akmaliah (1990), the success of the school's organization and leadership style is correlated. Transformational leadership of school principals affects student achievement and teacher willingness to drive for quality education (Noor Rezan, 2009). Abdul Shukor Abdullah (2004) argued that the leadership style of school principals have a significant impact on teachers' job satisfaction and effectiveness of the school. Changes to the leadership style of school principals should not only focus on the technical aspects of the schools administration but emphasize on professional leadership and guidance rendered to the teachers and students at the school. Hence, principals are solely responsible for the professional improvement of teachers to a higher level and to ensure students excel academically (Noor Rezan, 2009). Are the secondary school principals in Malaysia practicing transformational leadership in their management of school affairs? Also not much is known about the impact of transformational leadership style on the current situation at secondary schools in Malaysia. Creating conducive environment at schools for students to excel and teachers to perform professionally has placed more emphasis on the role of a principal. It is difficult to evaluate the attributes of principals at secondary schools who are committed to the mission and vision of cultivating a positive school environment.

At this point, no study has been done on transformational leadership behaviors' of the school principals in Malaysia although many studies have been conducted on other types of leadership. In order to assess the extent to which Malaysian secondary school principals provide transformational leadership, a survey of teachers' perceptions on their principals' transformational leadership behavior's will be carried out in the secondary schools in the state of Pulau Pinang and Kedah Darul Aman, Malaysia. This study hence was conducted to test the significant influence between principal's leadership styles and organizational health of secondary school teachers in Malaysia and the effects of school culture as a moderating variable.

\section{Objectives of the Study}

The study aimed to investigate the influence of transformational leadership and its relationship to organizational and school culture. In particular, the objectives of the study are:

1. To investigate the influence of transformational leadership on school culture of secondary schools in the state of Pulau Pinang and Kedah Darul Aman, Malaysia.

2. To investigate the influence of transformational leadership on organizational health of secondary schools in the state of Pulau Pinang and Kedah Darul Aman, Malaysia.

3. To investigate the influence of school culture on organizational health of secondary schools in the state of Pulau Pinang and Kedah Darul Aman, Malaysia.

4. To investigate the moderating influence of school culture on the relationship between transformational leadership and organizational health of secondary schools in the state of Pulau Pinang and Kedah Darul Aman, Malaysia. 


\section{Research Hypotheses of the Study}

Based on the research objectives, the research hypothesis was formed to test the validity. Research findings were tested at the level of $\mathrm{p}<0.05$. The following are the research hypotheses:

HA1: There is a significant influence of transformational leadership on school culture of secondary schools in the state of Pulau Pinang and Kedah Darul Aman, Malaysia.

HA2: There is a significant influence of transformational leadership on organizational health of secondary schools in the state of Pulau Pinang and Kedah Darul Aman, Malaysia.

HA3: There is a significant influence of school culture on organizational health of secondary schools in the state of Pulau Pinang and Kedah Darul Aman, Malaysia.

HA4: There is a significant moderating influence of school culture on the relationship between transformational leadership and organizational health of secondary schools in the state of Pulau Pinang and Kedah Darul Aman, Malaysia.

\section{Significance of the Study}

This study aims to benefit the school principals to identify approaches towards schools improvement and to create an atmosphere of well-being at work among teachers. It can motivate teachers to improve the teaching quality, especially in the classrooms. By doing so they will be able to produce students who will excel physically, emotionally, spiritually and intellectually in line with the national educational philosophy. This study will benefit the following parties:

- Ministry of Education: In recent years, the Malaysian education system has come under increased public scrutiny and debate, as parents' expectations rise and employers voice their concern regarding the system's ability to adequately prepare young Malaysians for the challenges of the 21st century (Malaysia Education Blueprint 2013-2025).

- Institut Aminuddin Baki: This study will also be significant to IAB to focus on management and leadership development training for school principals. The main institution in the country responsible for the training of school principals is IAB or in English, the National Institute of Educational Management and Leadership (NIEML) (IAB, 1997).

- School Principals: The data to be collected from this research will enable school principals to examine more closely the impact of their leadership style on the organizational health of their school. Based on the results of the questionnaire and data analysis, principals will be able to utilize the results to change and cultivate a healthier school culture.

- Complement Existing Knowledge: It is hoped that this study will complement existing literature regarding the influence of transformational leadership and organizational health of secondary schools in Malaysia. With increased literature and knowledge on school leadership behavior, prospective principals and all those involved in education may find the findings useful for identifying behaviors, beliefs and values that could advance the development of a school.

\section{Research Framework}

The research framework in this study is built upon the literature review. It is therefore theorized that each variable in transformational leadership style has an influence on organizational health of teachers. Figure 1 below depicts the research framework of this study:

Figure 1: The Research Framework

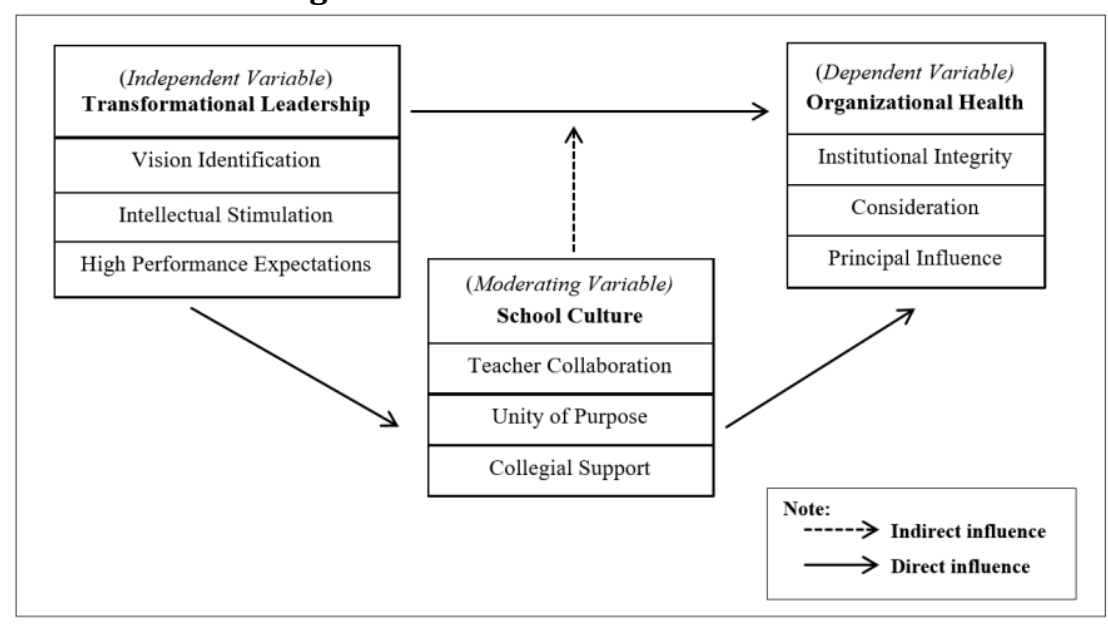




\section{Research Methodology}

\subsection{Research Design and Population Sampling}

According to Uma Sekaran (2003), descriptive study is undertaken when the characteristics or the phenomena to be tapped in a situation are known to exist and one wants to be able to describe them better by offering a profile of factors. It is suggested by Spunt (1999) that surveys with diverse type of questioning are a more convenient way of gathering information. Hence, this study chose this type of survey method as opposed to in -depth interviews or focus groups. Selfadministered surveys are more convenient and less expensive to administer, eliminates interviewer bias, gives respondents privacy and results can be analyzed more quickly. In this study a self-administered questionnaire consisting of four sections were used: Section A contains Teacher Demographic Information, Section B contains Principal Leadership Questionnaire (PLQ), Section C contains the School Culture Survey Questionnaire (SCS) and finally Section D consists of the Organizational Health Index for Secondary School Questionnaire (OHI-S).

In this study, the targeted population was teachers from national secondary schools from the state of Pulau Pinang and Kedah Darul Aman, Malaysia. A cover letter informed the participants that the aim of this research was to examine attitudes about work and leadership style and that they were to return the completed questionnaires in sealed envelopes within three to five days. Participants were encouraged to respond as accurately and honestly as possible, and they were assured that their participation would be kept confidential, anonymous and used strictly for academic research purposes only. A total of 650 structured questionnaires were distributed to teachers from 22 schools around Pulau Pinang and 35 schools around Kedah Darul Aman. The respondents were randomly selected by means of systematic random sampling, whereby 100 percent of the respondents were secondary school teachers.

A total of 496 questionnaires were received and out of this, 18 sets of the questionnaires were considered unusable because over 25 percent of the question in Part 1 Section A of the questionnaire were not answered (Sekaran, 2003). It was assumed that the respondents were either unwilling to cooperate or not serious with the survey. Therefore, only 478 usable sets of received questionnaires were used for the data analysis indicating a response rate of 73 percent.

Data were analyzed using SPSS v. 20 for Windows PC and is reported in percentage, frequency, mean and standard deviation. Descriptive statistics were used to obtain the frequency, percentage, mean and standard deviation. The inferential statistics of Multiple Regression Analysis and Moderated Multiple Regression Analysis (MMR) is used to identify if there is an influence between schools principals' transformational leadership with secondary school teacher's organizational health and the influence of the moderating variable; school culture.

\section{Findings}

\subsection{Testing the Influence of Transformational Leadership on School Culture}

The first hypothesis (HA1) about the influence of transformational leadership on school culture is tested using multiple regression analysis. The more detailed picture of the relationship between transformational leadership and school culture at construct and factor levels were revealed by the findings of regression analyses. Table 1 summarizes the regression results of the regression analysis at the construct level.

The data indicate that the transformational leadership style accounts for 65 percent of the variance in teacher collaboration (adjusted $R^{2} 0.651$ ). The $F$ test statistics for the adjusted $R^{2}$ is 228.97 and the associated $p$-value is .000 . It indicates that $p<.05$; therefore, a statistically significant relationship exists between teacher collaboration and the transformational leadership style at the 95.0 percent confidence level. The vision identification variable has positive effect on the teacher collaboration $(\beta=0.136)$ variable and this is statistically significant at the 95.0 percent confidence level because the t test statistics for the Beta is 18.43 and the associated $p$-value $(.000)$ is less than .05 .

As mentioned earlier, it is essential to point out the Beta $(\beta)$ weighting for the independent variables (vision identification, intellectual stimulation and high performance expectations) and dependent variable (teacher collaboration, unity of purpose and collegial support). The Beta $(\beta)$ weighting are calculated between the predictor variables and criterion variables. The intellectual stimulation variable has the strongest positive effect on the teacher collaboration $(\beta=0.327)$ 
variable and this is statistically significant at the 95.0 percent confidence level because the test statistics for the Beta is 18.43 and the associated p-value (.000) is less than .05 . The variable high performance expectations has a positive effect on teacher collaboration $(\beta=0.229)$ variable and this is statistically significant at the 95.0 percent confidence level because the $t$ test statistics for the Beta is 6.23 and the associated p-value (.001) is less than .05 .

\begin{tabular}{|c|c|c|c|}
\hline & \multicolumn{3}{|c|}{ Dependent Variable (School Culture) } \\
\hline Variable & $\begin{array}{c}1 \\
(\beta)\end{array}$ & $\begin{array}{c}2 \\
(\beta)\end{array}$ & $\begin{array}{c}3 \\
(\beta)\end{array}$ \\
\hline $\begin{array}{l}\text { Independent Variable } \\
\text { (Transformational } \\
\text { Leadership) }\end{array}$ & & & \\
\hline Vision Identification & $.136^{*}$ & $.439 *$ & -.185 \\
\hline $\begin{array}{l}\text { Intellectual } \\
\text { Stimulation }\end{array}$ & $.327 *$ & .084 & $.500^{*}$ \\
\hline $\begin{array}{l}\text { High Performance } \\
\text { Expectations }\end{array}$ & $.229^{*}$ & $.370^{*}$ & .098 \\
\hline $\mathrm{R}$ & 792 & .725 & .808 \\
\hline $\mathrm{R}^{2}$ & .654 & .526 & .653 \\
\hline Adjusted $\mathrm{R}^{2}$ & .651 & .521 & .651 \\
\hline F-statistics & 228.97 & 151.31 & 257.15 \\
\hline Durbin-Watson & 1.44 & 1.53 & 1.35 \\
\hline
\end{tabular}

*Significant at $p<.05$ 1= Teacher Collaboration, 2= Unity of Purpose, 3= Collegial Support

The regression results depicted from Table 1 indicates that the transformational leadership style accounts for 52 percent of the variance in unity of purpose (adjusted $\mathrm{R}^{2} 0.522$ ). The $\mathrm{F}$ test statistics for the adjusted $\mathrm{R}^{2}$ is 151.31 and the associated $p$-value is .001 . It indicates that $p<.05$; therefore, a statistically significant relationship exists between unity of purpose and the transformational leadership style at the 95.0 percent confidence level. Vision identification variable has the strongest positive effect on the unity of purpose $(\beta=0.439)$ variable and this is statistically significant at the 95.0 percent confidence level because the $t$ test statistics for the Beta is 10.81 and the associated $p$-value (.001) is less than .05 . The variable high performance expectations has a positive effect on unity of purpose $(\beta=0.370)$ variable and this is statistically significant at the 95.0 percent confidence level because the $t$ test statistics for the Beta is 9.1 and the associated $p$-value (.001) is less than .05 .

The regression results depicted from Table 1 indicates that the transformational leadership style accounts for 65 percent of the variance in collegial support (adjusted $\mathrm{R}^{2} 0.651$ ). The $\mathrm{F}$ test statistics for the adjusted $\mathrm{R}^{2}$ is 257.15 and the associated $\mathrm{p}$-value is .001 . It indicates that $p<.05$; therefore, a statistically significant relationship exists between collegial support and the transformational leadership style at the 95.0 percent confidence level. The intellectual stimulation variable has the strongest positive effect on the collegial support $(\beta=0.500)$ variable and this is statistically significant at the 95.0 percent confidence level because the $t$ test statistics for the Beta is 13.85 and the associated $p$-value (.001) is less than .05 . The result confirms the alternative hypothesis of transformational leadership as having a positive influence on school culture and is supported. Thus, the hypothesis HA1 is supported. All the 3 independent variables of transformational leadership; vision identification, intellectual stimulation and high performance expectations has positive and significant influence on school culture.

The second hypothesis (HA2) about the influence of transformational leadership on organizational health is tested using multiple regression analysis. Table 2 summarizes the regression results of the regression analysis at the construct level.

The regression results depicted from Table 2 indicates that the transformational leadership style accounts for 37 percent of the variance in institutional integrity (adjusted $\mathrm{R}^{2} 0.375$ ). The $\mathrm{F}$ test statistics for the adjusted $\mathrm{R}^{2}$ is 83.53 and the associated $\mathrm{p}$-value is .001 . It indicates that $p<.05$; therefore, a statistically significant relationship exists between institutional integrity and the transformational leadership style at the 95.0 percent confidence level. The high performance expectations variable has the strongest positive effect on the institutional integrity $(\beta=0.256)$ variable and this is statistically significant at the 95.0 percent confidence level because the test statistics for the Beta is 5.50 and the associated $p$-value (.001) is less than .05 . The variable vision identification has a positive effect on institutional integrity $(\beta=0.157)$ variable and this is 
statistically significant at the 95.0 percent confidence level because the test statistics for the Beta is 5.6 and the associated $p$-value $(.000)$ is less than .05 .

\begin{tabular}{|c|c|c|c|}
\hline \multirow[b]{2}{*}{ Variable } & \multicolumn{3}{|c|}{ Dependent Variable (Organizational Health) } \\
\hline & $\begin{array}{c}1 \\
(\beta)\end{array}$ & $\begin{array}{c}2 \\
(\beta)\end{array}$ & $\begin{array}{c}3 \\
(\beta)\end{array}$ \\
\hline \multicolumn{4}{|l|}{$\begin{array}{l}\text { Independent Variable } \\
\text { (Transformational } \\
\text { Leadership) }\end{array}$} \\
\hline Vision Identification & $.157^{*}$ & -.183 & .022 \\
\hline $\begin{array}{l}\text { Intellectual } \\
\text { Stimulation }\end{array}$ & -.182 & .063 & $.217^{*}$ \\
\hline $\begin{array}{l}\text { High Performance } \\
\text { Expectations }\end{array}$ & $.256^{*}$ & $.315^{*}$ & -.004 \\
\hline $\mathrm{R}$ & .616 & .575 & .438 \\
\hline $\mathrm{R}^{2}$ & .379 & .330 & .192 \\
\hline Adjusted $\mathrm{R}^{2}$ & .375 & .325 & .186 \\
\hline F-statistics & 83.53 & 67.35 & 32.45 \\
\hline Durbin-Watson & 1.72 & 1.22 & 1.81 \\
\hline
\end{tabular}

*Significant at $p<.05 \quad$ 1= Institutional Integrity, $2=$ Consideration, $3=$ Principal Influence

The regression results depicted from Table 2 indicates that the transformational leadership style accounts for 32.5 percent of the variance in consideration (adjusted $R^{2} 0.325$ ). The $F$ test statistics for the adjusted $\mathrm{R}^{2}$ is 67.35 and the associated $\mathrm{p}$-value is .001 . It indicates that $p<.05$; therefore, a statistically significant relationship exists between consideration and the transformational leadership style at the 95.0 percent confidence level. The high performance expectations variable has the strongest positive effect on the consideration $(\beta=0.315)$ variable and this is statistically significant at the 95.0 percent confidence level because the test statistics for the Beta is 4.43 and the associated p-value (.001) is less than .05.

The regression results depicted from Table 2 indicates that the transformational leadership style accounts for 18 percent of the variance in principal influence (adjusted $\mathrm{R}^{2} 0.186$ ). The $\mathrm{F}$ test statistics for the adjusted $\mathrm{R}^{2}$ is 32.45 and the associated $\mathrm{p}$-value is .001 . It indicates that $p<.05$; therefore, a statistically significant relationship exists between principal influence and the transformational leadership style at the 95.0 percent confidence level. The intellectual stimulation variable has the strongest positive effect on the principal influence $(\beta=0.217)$ variable and this is statistically significant at the 95.0 percent confidence level because the test statistics for the Beta is 6.73 and the associated $p$-value (.001) is less than .05 . The result confirms the alternative hypothesis of transformational leadership as having a positive influence on organizational health and is supported. Thus, the hypothesis HA2 is supported. All the 3 independent variables of transformational leadership; vision identification, intellectual stimulation and high performance expectations has positive and significant influence on organizational health.

The third hypothesis (HA3) about the influence of school culture on organizational health is tested using multiple regression analysis. Table 3 summarizes the regression results of the regression analysis at the construct level.

The regression results depicted from Table 3 indicates that the school culture accounts for 31 percent of the variance in institutional integrity (adjusted R2 0.309). The F test statistics for the adjusted $\mathrm{R}^{2}$ is 52.34 and the associated $p$-value is .001. It indicates that $p<.05$; therefore, a statistically significant relationship exists between institutional integrity and school culture at the 95.0 percent confidence level. The collegial support variable has the strongest positive effect on the institutional integrity $(\beta=0.218)$ variable and this is statistically significant at the 95.0 percent confidence level because the t test statistics for the Beta is 4.18 and the associated p-value (.001) is less than .05. The variable teacher collaboration has a positive effect on institutional integrity $(\beta=$ 0.198 ) variable and this is statistically significant at the 95.0 percent confidence level because the $t$ test statistics for the Beta is 5.81 and the associated p-value (.001) is less than .05.

The regression results depicted from Table 3 indicates that the school culture accounts for 50 percent of the variance in consideration (adjusted $R^{2} 0.501$ ). The $F$ test statistics for the adjusted $\mathrm{R}^{2}$ is 116.07 and the associated $\mathrm{p}$-value is .001 . It indicates that $p<.05$; therefore, a statistically significant relationship exists between consideration and school culture at the 95.0 percent confidence level. The teacher collaboration variable has the strongest positive effect on the consideration $(\beta=0.462)$ variable and this is statistically significant at the 95.0 percent confidence 
level because the $t$ test statistics for the Beta is 5.51 and the associated p-value (.001) is less than .05 . The variable collegial support has a positive effect on consideration $(\beta=0.283)$ variable and this is statistically significant at the 95.0 percent confidence level because the test statistics for the Beta is 3.82 and the associated $p$-value (.001) is less than .05 .

Table 3: The Influence of School Culture on Organizational Health

\begin{tabular}{|c|c|c|c|}
\hline \multirow[b]{2}{*}{ Variable } & \multicolumn{3}{|c|}{ Dependent Variable (Organizational Health) } \\
\hline & $\begin{array}{c}1 \\
(\beta)\end{array}$ & $\begin{array}{c}2 \\
(\beta)\end{array}$ & $\begin{array}{c}3 \\
(\beta)\end{array}$ \\
\hline \multicolumn{4}{|l|}{$\begin{array}{l}\text { Independent Variable } \\
\text { (Transformational } \\
\text { Leadership) }\end{array}$} \\
\hline $\begin{array}{l}\text { Teacher } \\
\text { Collaboration }\end{array}$ & $.198^{*}$ & $.462^{*}$ & $.543^{*}$ \\
\hline Unity of Purpose & -.016 & .051 & $.268^{*}$ \\
\hline Collegial Support & $.218^{*}$ & $.283^{*}$ & $.210^{*}$ \\
\hline $\mathrm{R}$ & .561 & .711 & .491 \\
\hline $\mathrm{R}^{2}$ & .315 & .505 & .241 \\
\hline Adjusted $\mathrm{R}^{2}$ & .309 & .501 & .234 \\
\hline F-statistics & 52.34 & 116.07 & 36.03 \\
\hline Durbin-Watson & 1.70 & 1.75 & 1.90 \\
\hline
\end{tabular}

*Significant at $p<.05 \quad$ 1= Institutional Integrity, $2=$ Consideration, $3=$ Principal Influence

The regression results depicted from Table 3 indicates that the school culture accounts for 23 percent of the variance in consideration (adjusted $R^{2} 0.234$ ). The $F$ test statistics for the adjusted $\mathrm{R}^{2}$ is 36.03 and the associated $\mathrm{p}$-value is .000 . It indicates that $p<.05$; therefore, a statistically significant relationship exists between principal influence and school culture at the 95.0 percent confidence level. The teacher collaboration variable has the strongest positive effect on the consideration $(\beta=0.543)$ variable and this is statistically significant at the 95.0 percent confidence level because the t test statistics for the Beta is 11.48 and the associated p-value (.001) is less than .05. The variable unity of purpose has a positive effect on principal influence $(\beta=0.268)$ variable and this is statistically significant at the 95.0 percent confidence level because the test statistics for the Beta is 3.95 and the associated p-value $(.001)$ is less than .05 . Whereas, the variable collegial support also has a positive effect on principal influence $(\beta=0.210)$ variable and this is statistically significant at the 95.0 percent confidence level because the t test statistics for the Beta is 3.99 and the associated p-value (.001) is less than .05.

The result confirms the alternative hypothesis of school culture as having a positive influence on organizational health and is supported. Thus, the hypothesis HA3 is supported. All the 3 independent variables of school culture; teacher collaboration, unity of purpose and collegial support has positive and significant influence on organizational health.

\subsection{Testing the Moderating Influence of School Culture on the Relationship between Transformational Leadership and Organizational Health}

Hypothesis HA4 addressed the moderating influence of school culture on the relationship between transformational leadership and organizational health. The role of school culture variables as a moderator variable will be identified from the significance of the interaction coefficient between the interaction terms (transformational leadership $\mathrm{x}$ school culture). A positive and significant coefficient indicates that school culture moderates the relationship between transformational leadership and organizational health outcomes. Higher relative scores on school culture will increase the magnitude of the effect between transformational leadership and organizational health outcomes. Results of the MMR analysis for the interaction effect between transformational leadership and school culture are shown in Table 4.

Analyses for moderating influence for the above hypothesis are tested by performing MMR analysis with institutional integrity, consideration and principal influence as the respective dependent variables. In each of these regressions, institutional integrity as control variable was entered in Step 1, transformational leadership variables (vision identification, intellectual stimulation and high performance expectations) and school culture variables (teacher collaboration, unity of purpose and collegial support) as main effect variables were entered in Step 2 and the interaction term of transformational leadership variables and school culture variables 
were entered in Step 3. Results of the MMR analysis for the interaction effect between transformational leadership and school culture are shown in Table 4.

The MMR analysis shown in Table 4 revealed that the full model (Step 1, 2 \& 3) includes the control variable, the independent variables, the moderator variable and the interaction terms of the moderator variable and independent variables. Step 1 show that three variables (vision identification, intellectual stimulation and high performance expectations) have a positive and significant relationship with organizational health variable (institutional integrity). The vision identification variable $(\beta=.323, p=.000)$; intellectual stimulation $(\beta=.211, p=.000)$ and high performance expectations $(\beta=.118, p=.000)$.

Transformational leadership variables and teacher collaboration variable as main effect variables were entered in Step 2 and the result shows three variables has positive and significant relationship with institutional integrity. The vision identification variable $(\beta=.357, p=.000)$; intellectual stimulation variable $(\beta=.239, \mathrm{p}=.000)$ and high performance expectations variable $(\beta=.103, p=.008)$.

The interaction terms of transformational leadership variables and teacher collaboration variable were entered in Step 3. Interaction term shows two variables have significant relationship with institutional integrity. The vision identification variable $(\beta=-.189, p=.000)$ and high performance expectations $(\beta=.258, p=.000)$.

The results of the MMR analysis for the interaction effect between transformational leadership and school culture suggests that the exploratory power of the model increases because of the inclusion of the interaction term. As shown in Table 4, an additional 2.3 percent of variance $\left(\Delta \mathrm{R}^{2}=0.023, p<.05\right)$ in institutional integrity was explained by the inclusion of the interaction term. Thus, the results indicate the evidence that teacher collaboration moderates the relationship between transformational leadership and institutional integrity.

To interpret the effect of the interaction term of teacher collaboration (TC), simple regression equations were produced where the influence of teacher collaboration on the relationship between vision identification (VI) and institutional integrity was revealed. The statistical significance of the slope of these simple regression equations were also analyzed and established. The simple regression equations, detailed in Figure 2 indicated a significant $(p<0.05)$ negative regression of institutional integrity on vision identification at the level of teacher collaboration interaction. Examination of the interaction plot (Figure 2) showed an enhancing effect that if vision identification increased, teacher collaboration decreased. In other words, institutional integrity lowers the effects of vision identification on teacher collaboration. If the degree to which the principal's behavior is aimed at identifying new opportunities for his/her teachers and inspiring them to work towards school mission, the teachers engage less in constructive dialogue that furthers the vision of the school.

Figure 2: Results of Moderator Analysis: Influence of Teacher Collaboration

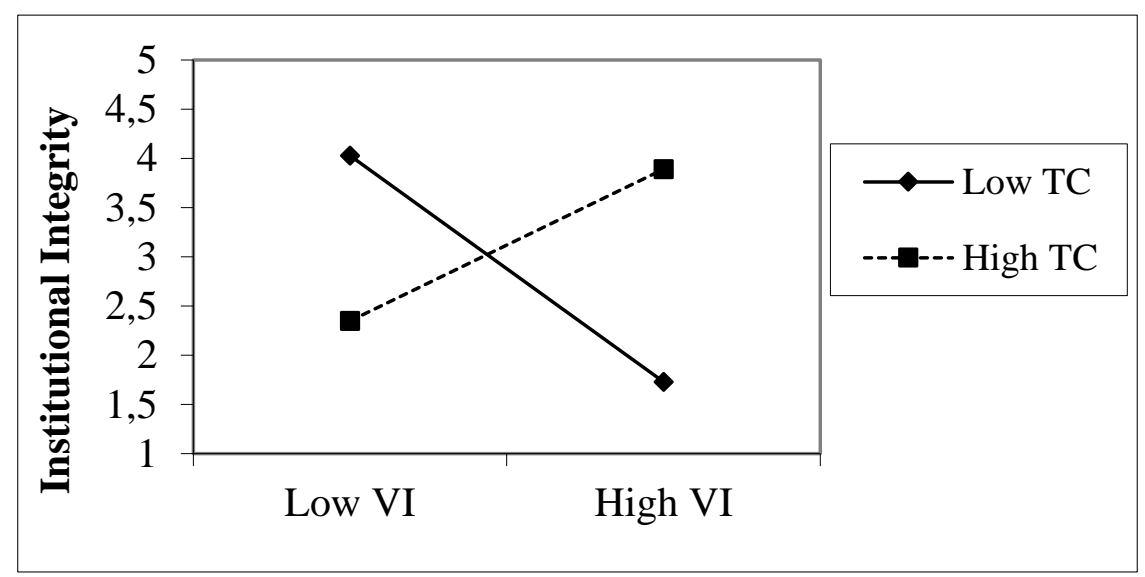

The simple regression equations, detailed in Figure 4 indicated a significant $(\mathrm{p}<0.05)$ positive regression of institutional integrity on high performance expectations at the level of teacher collaboration interaction. Examination of the interaction plot (Figure 3) showed an enhancing effect that if high performance expectations increased, teacher collaboration also increased. In other words, institutional integrity will increase if high performance expectations and teacher collaboration is high. If the degree to which the principal's expectations for excellence, quality and high performance on the part of the teachers is high, the teachers tend to plan together, observe and discuss teaching practices, evaluate programs and develop an awareness of the practices and programs of other teachers and collectively work towards school's mission. 


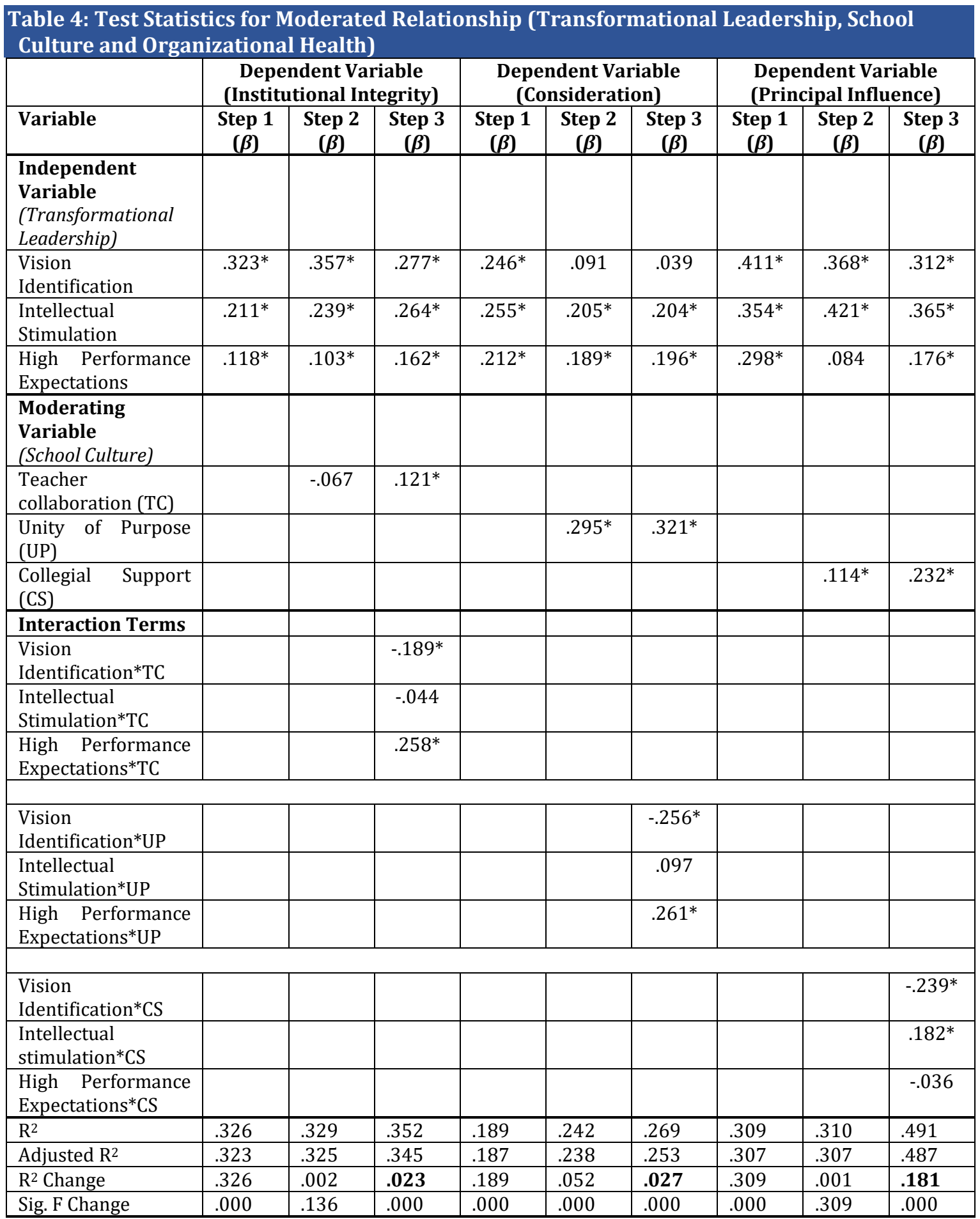

* Significant at $p<.05$

Figure 3: Results of Moderator Analysis: Influence of Teacher Collaboration

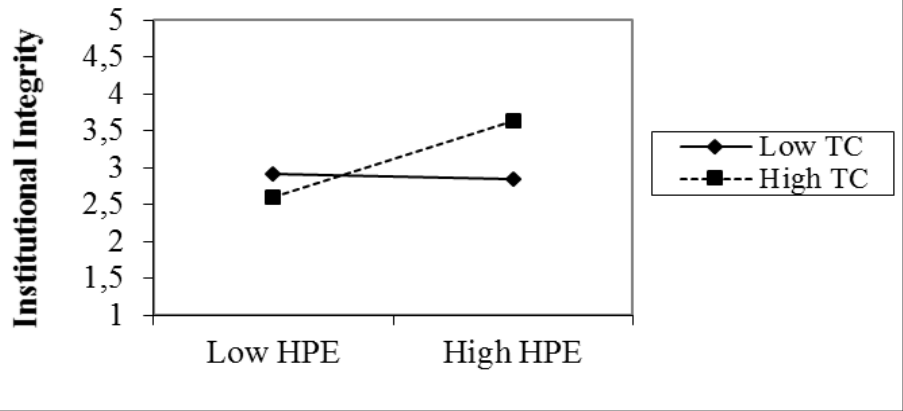


The MMR analysis shown in Table 4 revealed that the full model (Step 1, 2 \& 3) includes the control variable, the independent variables, the moderator variable and the interaction terms of the moderator variable and independent variables. Step 1 show that three variables (vision identification, intellectual stimulation and high performance expectations) have a positive and significant relationship with organizational health variable (consideration). The vision identification variable $(\beta=.246, p=.000)$; intellectual stimulation $(\beta=.255, p=.000)$ and high performance expectations $(\beta=.212, \mathrm{p}=.000)$.

Transformational leadership variables and unity of purpose variable as main effect variables were entered in Step 2 and the result shows three variables has positive and significant relationship with institutional integrity. The intellectual stimulation variable $(\beta=.205, p=.000)$, high performance expectations variable $(\beta=.189, p=.008)$ and unity of purpose $(\beta=.295, p=.000)$

The interaction terms of transformational leadership variables and unity of purpose variable were entered in Step 3. Interaction term shows three variables have significant relationship with consideration. The vision identification variable $(\beta=-.256, p=.000)$, intellectual stimulation $(\beta=$ $.164, p=.000)$ and high performance expectations $(\beta=.261, p=.000)$.

The results of the MMR analysis for the interaction effect between transformational leadership and school culture suggests that the exploratory power of the model increases because of the inclusion of the interaction term. As shown in Table 4, an additional 2.7 percent of variance $(\Delta \mathrm{R} 2=0.027, \mathrm{p}<.05)$ in consideration was explained by the inclusion of the interaction term. Thus, the results indicate the evidence that unity of purpose moderates the relationship between transformational leadership and consideration.

To interpret the effect of the interaction term of unity of purpose (UP), simple regression equations were produced where the influence of unity of purpose on the relationship between vision identification (VI) and consideration was revealed. The statistical significance of the slope of these simple regression equations were also analyzed and established. The simple regression equations, detailed in Figure 4 indicated a significant $(\mathrm{p}<0.05)$ negative regression of consideration on vision identification at the level of unity of purpose interaction. Examination of the interaction plot (Figure 4) showed an enhancing effect that if vision identification increased, unity of purpose decreased. In other words, consideration lowers the effects of vision identification on unity of purpose. If the degree to which the principal's behavior is demonstrating low levels of consideration, the teachers performed low quality work, appeared more dissatisfied and perceived the leader as ineffective. Teachers don't understand, support or perform in accordance with school's mission.

Figure 4: Results of Moderator Analysis: Influence of Unity of Purpose

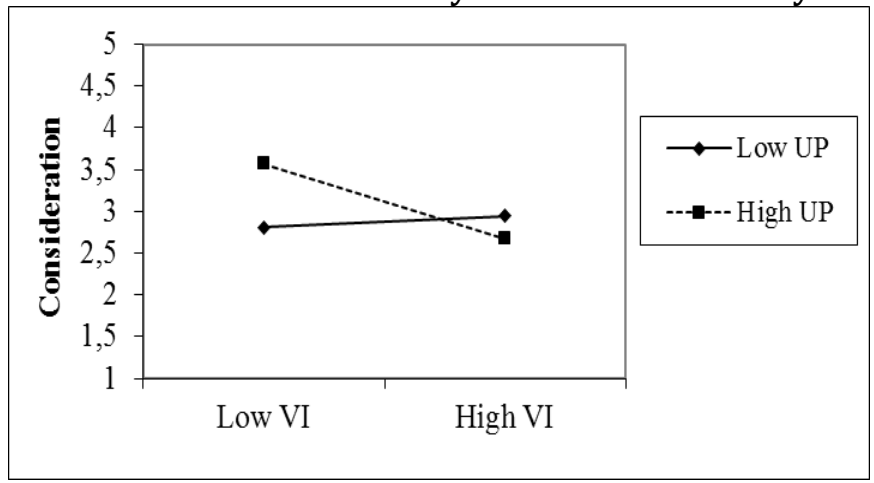

The MMR analysis shown in Table 4 revealed that the full model (Step 1, 2 \& 3) includes the control variable, the independent variables, the moderator variable and the interaction terms of the moderator variable and independent variables. Step 1 show that three variables (vision identification, intellectual stimulation and high performance expectations) have a positive and significant relationship with organizational health variable (principal influence). The vision identification variable $(\beta=.411, p=.000)$; intellectual stimulation $(\beta=.354, p=.000)$ and high performance expectations $(\beta=.298, p=.000)$.

Transformational leadership variables and collegial support variable as main effect variables were entered in Step 2 and the result shows three variables has positive and significant relationship with principal influence. The vision identification variable $(\beta=.368, p=.000)$, intellectual stimulation variable $(\beta=.421, \mathrm{p}=.008)$ and collegial support $(\beta=.114, \mathrm{p}=.000)$

The interaction terms of transformational leadership variables and collegial support variable were entered in Step 3. Interaction term shows two variables have significant relationship with 
principal influence. The vision identification variable $(\beta=-.239, \mathrm{p}=.000)$ and intellectual stimulation $(\beta=.182, p=.000)$.

The results of the MMR analysis for the interaction effect between transformational leadership and school culture suggests that the exploratory power of the model increases because of the inclusion of the interaction term. As shown in Table 4, an additional 18.1 percent of variance $(\Delta \mathrm{R} 2=0.181, \mathrm{p}<.05)$ in consideration was explained by the inclusion of the interaction term. Thus, the results indicate the evidence that collegial support moderates the relationship between transformational leadership and principal influence.

To interpret the effect of the interaction term of collegial support (CS), simple regression equations were produced where the influence of collegial support on the relationship between vision identification (VI) and principal influence was revealed. The statistical significance of the slope of these simple regression equations were also analyzed and established. The simple regression equations, detailed in Figure 5 indicated a significant $(p<0.05)$ negative regression of principal influence on vision identification at the level of collegial support interaction. Examination of the interaction plot (Figure 5) showed an enhancing effect that if vision identification increased, collegial support decreased. In other words, principal influence lowers the effects of vision identification on collegial support. If the degree to which the principal's influence is low, the teachers performed low quality work, cannot work together effectively, don't trust each other as they work to accomplish the tasks of the school's organization.

Figure 5: Results of Moderator Analysis: Influence of Collegial Support

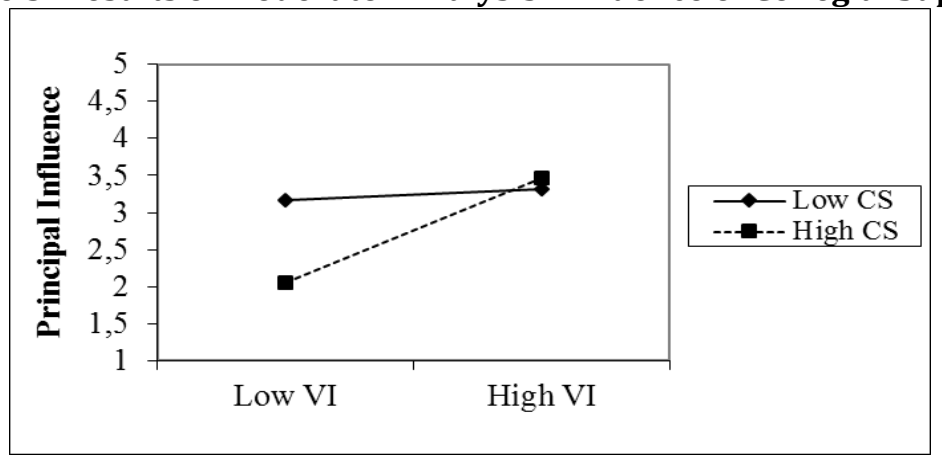

To interpret the effect of the interaction term of collegial support (CS), simple regression equations were produced where the influence of collegial support on the relationship between intellectual stimulation and principal influence was revealed. The statistical significance of the slope of these simple regression equations were also analyzed and established. The simple regression equations, detailed in Figure 6 indicated a significant $(\mathrm{p}<0.05)$ positive regression of principal influence on intellectual stimulation at the level of collegial support interaction. Examination of the interaction plot (Figure 6) showed an enhancing effect that if vision identification increased, collegial support decreased. In other words, intellectual stimulation and collegial support has inverse correlation when principal influence is low. The principal's ability to influence the actions of the teachers is decreased and the collegial behavior among teachers is low. Teachers are of the opinion that the principal lacks respect and concern for their well-being. The results confirm the alternative hypothesis of teacher collaboration having a moderating influence on the relationship between transformational leadership and organizational health and are accepted. Thus, the hypothesis HA4 is supported.

Figure 6: Results of Moderator Analysis: Influence of Collegial Support

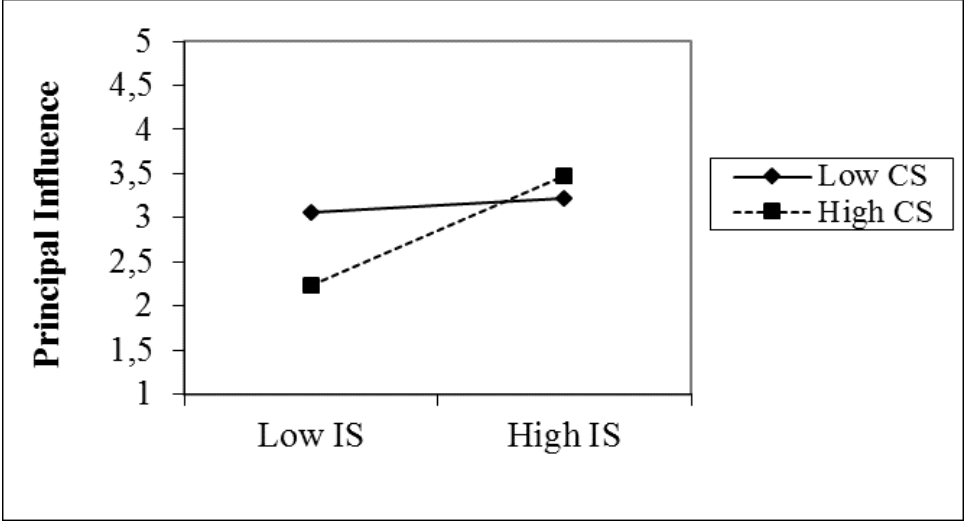




\section{Conclusion}

One of the primary objectives of this study was to examine the influence of transformational leadership on school culture of secondary schools in the states of Pulau Pinang and Kedah Darul Aman, Malaysia as perceived by teachers. Many previous researchers have found that transformational leadership had a significant positive contribution to school culture (Yaakob Daud, 2007; Penny, Townsend \& Cummins, 2003; Den Hartog, Van Muijen \& Koopman, 1997).

The results of this present study support the influence of transformational leadership on school culture. Many previous researchers have found that transformational leadership had a significant positive contribution to organizational health (Alqudah, 2011; Shastri et al., 2010). Another interesting finding in this study is that vision identification, intellectual stimulation and high performance expectations indicated a positive significant influence. A transformational leadership principal sees the value in developing people by giving personal attention to teachers (Bass, 1990), assisting teachers when they are struggling personally or professionally (Bass, 1990) and showing concern about teachers' needs and feelings (Jantzi \& Leithwood, 1996). In fact, past studies have demonstrated that transformational leadership encourages employees to have higher levels of commitment (Avolio et al., 2004; Hitam, Torsiman \& Balakrishnan, 2011). The results of this present study support the influence of transformational leadership on organizational health. Organizational health is widely described in the management and behavioral sciences literature as a key factor in the relationship between individuals and organizations. For example, Abdul Ghani Kanesan et al. (2015) state the organizational health as the important element that increases or promote the ties or attachment of the individual to the organization.

Many previous researchers have found that school culture had a significant positive contribution to organizational health (Lunenburg \& Ornstein, 2008; Arham Baharin \& Ahmad Muhaimin, 2006). The results of this present study support the influence of school culture on organizational health. The findings indicate a positive and statistically significant influence between vision identification and high performance expectations. A study conducted by Saphier, King and D'Auria (2006) supported that institutional integrity indicated a strong, positive and significant relationship existed between school culture and the organizational health dimension. Furthermore, the relationship between each component of school culture and organizational health was found to be moderate, positive, negative and significant. The results indicate that teacher collaboration moderates the relationship between transformational leadership and organizational health. The vision identification, intellectual stimulation and high performance expectations variables shows significant relationship with organizational health variable. Teacher collaboration is important for student achievement. Fullan (1999) suggested that successful schools were those with the culture that encouraged teachers to work collaboratively. As teachers collaborate, they develop stronger institutional strategies and these strategies ultimately enhance student achievement (Marzano, Waters \& McNulty, 2005). The current body of literature has suggested that vision identification has the potential to improve teacher collaboration and serve as a catalyst for a healthier school but the negative significant influence of vision identification indicated the degree to which the principal's behavior is aimed at identifying new opportunities for his staff and inspiring them to work towards school mission, the teachers engage less in constructive dialogue that furthers the educational vision of the school. The significant negative influence could indicate that teachers and principals working together for the common good of the students seem less promising.

The results indicate that unity of purpose moderates the relationship between transformational leadership and organizational health. The vision identification and high performance expectations variables shows significant relationship with organizational health variable. Unity of purpose explains the degree to which teachers work together to achieve the school's mission. The mission is clearly communicated to the teachers and the teachers are supportive of its purpose. As a result, their job performance is guided by these values (Gruenert, 1998). According to Peterson (2002), effective leaders can successfully create a shared vision and build a sense of commitment among all stakeholders. The results indicate that collegial support moderates the relationship between transformational leadership and organizational health. The vision identification and high performance expectations variables show significant relationship with organizational health variable. Collegial support measures the degree to which teachers engage in constructive dialogue that furthers the educational efficiency of the school. A high score on this factor means that teachers trust each other and value each other's ideas, plan together, observe and discuss teaching practices and assist each other as they work to accomplish the tasks (Cavanagh et al., 1998). The findings of this study lends support to Leithwood et al.'s (2008) proposition that transformational leaders help build a collaborative relationship between the leader and the follower which ultimately impacts the performance of the whole organization resulting in a responsive and modern environment. 


\section{Theoretical Implication}

The main purpose of the design of the research framework of the study was to investigate the influence of intermediary in this study. The study found that school culture functions as a moderator in the relationship between the transformational leadership style of school principals' and the organizational health of the secondary schoolteachers' in the states of Pulau Pinang and Kedah Darul Aman, Malaysia. Therefore, the design of the study's framework established in this research gives the impression based on theories and models used. In addition, school culture as a moderator in the relationship between transformational leadership and organizational health is a new discovery in the field of leadership. This is because the organizational health of secondary schools has never been investigated by local researchers. Most previous studies have highlighted transformational leadership and school culture has a direct influence on school improvement.

\section{Practical Implication}

This study discussed the moderating role of school culture on the relationship between transformational leadership and the organizational health (motivation, job satisfaction and trust of employees) of secondary school teachers. The findings of this study can be used by practitioners in the Malaysian national secondary schools, to improve their approach to motivating their employees and to increase their level of job satisfaction. One of the many ways a school principal can inculcate a positive school culture is by "shaping the school's instructional culture", which in turn shapes "the attitudes of teachers, students, parents and the community at large towards education". By effectively managing this aspect of a school's culture, principals can "increase both student and teacher motivation and indirectly impact learning gains".

Effective leadership practices can provide a way of encouraging and inspiring secondary school teachers, so that they have a vision that is shared with the schools goals, which can improve organizational performance. One of the key findings from this study is the "vision identification" variable which showed significant negative regression on all 3 variables of school culture. If the principals are trained with the right vision identification paradigm towards achieving the school's objectives and goals, they can accurately emulate this to their staffs via training, seminars and dialogues. Leaders who build positive relationships with their followers are able to foster their staffs' willingness to share their knowledge with other members of the school. Transformational leadership would not only drive followers forward, it would also inspire them to pursue a shared vision, through which they would act as school representatives. In a sense, followers would be encouraged to join in a society that encourages them to adopt the characteristics, culture and beliefs of the school. It is generally understood that the real source of the authority of the principal lies not in their position, but in their ability to encourage and inspire staffs to share a vision and commit both their heart and minds to their work.

\section{Appendix A. Supplementary material}

Supplementary data associated with this article can be found, in the online version, at http://dx.doi.org/10.14254/jems.2017.2-1.2

\section{Funding}

The authors received no direct funding for this research.

\section{Citation information}

Arokiasamy, A. R. (2017). Moderating influence of school culture on the relationship between transformational leadership and organizational health of secondary school teachers in Malaysia. Economics, Management and Sustainability, 2(1), 19-35. doi:10.14254/jems.2017.2-1.2.

\section{References}

Arokiasamy, A. R. A., Abdullah, A. G. K., Ahmad, M. Z., \& Ismail, A. (2016). Transformational Leadership of School Principals and Organizational Health of Primary School Teachers in Malaysia. Procedia-Social and Behavioral Sciences, 229, 151-157.

Abdullah, A. G. K., \& Arokiasamy, A. R. A. (2016). The Influence of School Culture and Organizational Health of Secondary School Teachers in Malaysia. Tem Journal-Technology Education Management Informatics, 5(1), 56-59. doi:10.18421/TEM51-09. 
Abdullah, A. (2004). Kepimpinan unggul tonggak pengurusan pendidikan Cemerlang. Jurnal Pengurusan dan Kepimpinan Pendidikan, 14(1), 18-30.

Alqudah, T. G. (2011). Leadership style and organizational commitment. MBA dissertation, Kuala Lumpur: Open University Malaysia.

Abdullah, A. Mesir, B., \& Mohamad, A. (2006). Faktor-faktor Yang Menyumbang Kepada Kecemerlangan Akademik Pelajar di Universiti Teknologi Malaysia, Universiti Teknologi Malaysia. Kajian Kes.

Avolio, B. J., Zhu, W., Koh, W., \& Bhatia, P. (2004). Transformational leadership and organizational commitment: mediating role of psychological empowerment and moderating role of structural distance. Journal of Organizational Behavior, 25, 951-968.

Bass, B. M. (1990). From transactional to transformational leadership: Learning to share the vision. Organizational Dynamics, 18(3), 19-31.

Bass, B. M., \& Avolio, B. J. (2003). Improving Organizational Effectiveness through Transformational Leadership. Thousand Oaks, Sage Begley, P \& Johansson, O. The Ethical Dimensions of School Leadership, Dordrecht, Kluwer Academic Publishers.

Bass, B. M., \& Riggio, R. E. (2006). Transformational leadership (2nd ed.). Mahwah, NJ: Lawrence Erlbaum Associates.

Bogler, R., (2001). The influence of leadership style on teacher job satisfaction. Educational Administration Quarterly, 37(5), 662-683.

Brown, M. E., Treviño, L. K., \& Harrison, D. (2005). Ethical leadership: A social learning perspective for construct development and testing. Organizational Behavior and Human Decision Processes, 97, 117-134.

Cavanaugh, R. F., \& Dellar, G. B. (1998). The development, maintenance and transformation of school culture. Paper presented at the meeting of the American Educational Research Association, San Diego, CA.

Cemaloglu, N., Sezgin, F., \& Killing, A.C. (2012). Examining the Relationships between School Principals' Transformational and Transactional Leadership Styles and teachers Organizational Commitment. The Online Journal of New Horizons in Education, 2(2), 53-63.

Creswell, J. W. (2005). Educational research. Planing, conducting and evaluating qualitative and quantitative approaches (3rd ed.). Thousand Oaks, CA: Sage Publications, Inc.

Den Hartog, D.N., Van Muijen, J.J., \& Koopman, P.L. (1997). Transactional versus transformational leadership: An analysis of the MLQ. Journal of Occupational and Organizational Psychology, 70(1), 19-34.

Fleishman E. A., \& Harris, E. F. (1962). Patterns of leadership behavior related to employee grievances and turnover. Personnel Psychology, 15, 43-56.

Fullan, M. G. (1999). The new meaning of educational change. (2 ${ }^{\text {nd }}$ ed.) New York: Teachers College Press.

Gruenert, S. (1998). School Culture Survey. Unpublished doctoral dissertation, University of Missouri, Columbia.

Geijsel, F., Sleegers, P., Leithwood, K., \& Jantzi, D. (2003).Transformational leadership effects on teachers' commitment and effort toward school reform. Journal of Educational Administration, 41(3), 228-256.

Gersten, R., Keating, T., Yovanoff, P., \& Harniss, M. (2001). Working in special education: Factors that enhance special educators' intent to stay. The Council for Exceptional Children, 67(4), 549567.

Griffith, J. (2004). Relation of principal transformational leadership to school staff job satisfaction, staff turnover, and school performance. Journal of Educational Administration, 42(3), 333356.

Hallinger, P. (2003). Leading educational change: Reflections on the practices of instructional and transformational leadership. Cambridge Journal of Education, 33(3), 329-351. http://dx.doi.org/10.1080/0305764032000122005. 
Hallinger, P. (2007). Leadership for Learning: Reflections on the practices of instructional and transformational leadership. Paper presented, Seminar at East Asia University.

Harris, A., \& Chapman, C. (2002). Effective leadership in school facing challenging circumstances. Nottingham: National College for School Leadership.

Harris, A., Day, C., Hopkins, D., Hadfield, M., Hargreaves, A., \& Chapman, C. (2013). Effective leadership for school improvement. London: Routledge.

Heller, H. W., Clay, R., \& Perkins, C. (1993). The relationship between teacher job satisfaction and principal leadership style. Journal of School Leadership, 3, 74-86.

Hersey, P., \& Blanchard, K. H. (1996). The management of organizational behavior (7 ed.). Englewood Cliffs, NJ: Prentice-Hall.

Hoy, W. K., Tarter, C. J., \& Kottkamp, R. B. (1991). Open schools/healthy schools: Measuring organizational climate. Beverly Hills, CA: Sage.

Hoy, W. K., \& Miskel, C. G. (2013). Educational administration. Theory, research, and practice (9th ed.), New York, NY: McGraw Hill.

Leithwood, K., \& Jantzi, D. (in press). A review of transformational school leadership research: 1996 - 2005. Leadership and Policy in Schools.

Leithwood, K., Jantzi, D., \& Mascall, B. (2002). Large-scale reform: What works. Journal of Educational Change, 3(1), 7-33.

Leithwood, K., Jantzi, D., \& Steinbach, R. (1999). Changing leadership for changing times. Buckingham, UK: Open University Press.

Leithwood, K., Jantzi, D., Earl, L., Fullan, M., Levin, B. (2004). Leadership for large-scale reform. School Leadership and Management, 24(1), 57-80.

Littrell, P.C., Billingsley, B. \& Cross, L. (1994). The effects of principal support on special an general educators' stress, job satisfaction, school commitment, health, and intent to stay in teaching. Remedial and Special Education, 15, 297-310.

Lunenburg,F., \& Ornstein, Allan (2008). Educational administration: Concepts and practices. ( 2 nd ed.), Belmont, CA: Wadsworth Publishing Company.

Locke, E. (1969). What is job satisfaction? Organizational Behavior and Human Performance, 4, 309336.

Marmaya, N., Hitam, M., Torsiman, N. M., \& Balakrishnan, B. (2011). Employees' perceptions of Malaysian managers' leadership styles and organizational commitment. African Journal of Business Management, 5(5), 1584-1588.

Marzano, R. J., Waters, T., \& McNulty, B. (2005). School leadership that works: From research to results. Alexandria, VA: Association for Supervision and Curriculum Development.

McLeskey, J., Tyler, N.C., \& Flippin, S.S. (2004). The supply and demand of for special education teachers: A review of research regarding the chronic shortage of special education teachers. The Journal of Special Education, 38(1), 5-21.

Ministry of Education. (2012). Malaysian Education Blueprint 2013-2025. Ministry of Education Malaysia.

Muijs, D., Harris, A., Chapman, C., Stoll, L., \& Russ, J. (2004). Improving schools in socioeconomically disadvantaged areas-A review of research evidence. School effectiveness and school improvement, 15(2), 149-175.

Hashim, N. R. B. (2009). Sekolah Kluster Lonjak Institusi Pendidikan (Cluster School Accelerate the Educational Institutions) in. Majalah Pendidik (Educators Digest), 18-21.

Nguni, S., Sleegers, P., \& Denessen, E. (2006). Transformational and transactional leadership effects on teachers' job satisfaction, organizational commitment, and organizational citizenship behavior in primary schools: The Tanzanian case. School effectiveness and school improvement, 17(2), 145-177.

Peterson, K. (2002). Principals and student achievement: What the research says. Alexandria, VA: Association for Supervision and Curriculum Development. 
Rahman Sukor bin Abdul Samad (2010). Education management in the context of quality improvement: managing change for improving learning community. Jurnal Pendidikan, 30(2), 93-108.

Reitzug, U \& Patterson, J, (1998). "I'm not going to lose you!": Empowerment through caring in an urban principal's practice with pupils, Urban Education, 33(2), 150-81.

Saphier, J., King, M., \& D’Auria, J. (2006). 3 strands form strong school leadership. Journal of Staff Development, 27, 51-59.

Shastri, R., Mishra, K. S., \& Sinha, A. (2010). Charismatic leadership and organizational commitment: An Indian perspective. African Journal of Business Management, 4(10), 1946-1953.

Selamat, N., Nordin, N., \& Adnan, A.A. (2013). Rekindle teachers' organizational commitment: The effect of Transformational leadership behavior. Procedia Social and behavioral sciences, 90, 566-574. http://dx.doi.org/10.1016/j.sbspro.2013.07.127.

Seltzer, J., \& Bass, B.M. (1990). Transformational Leadership: Beyond Initiation and Consideration. Journal of Management, 16 (4), 693- 703.

Silins, H., \& Mulford, B. (2002). Leadership and school results. In Second international handbook of educational leadership and administration (pp. 561-612). Springer Netherlands.

Spector, P. (1997). Job Satisfaction: Application, Assessment, Causes and Consequences. California: Sage.

Styron Jr, R. A., \& Nyman, T. R. (2008). Key characteristics of middle school performance. RMLE Online, 31(5), 1-17.

Spunt, T. M. (1999). Guide to customer surveys : Sample questionnaires and detailed guidelines for creating effective surveys. New York, NY: Customer Service Group.

Uma, Sekaran, (2000). Research Methods for Business: A Skill-building Approach. Third Ed. New York: John Wiley \& Sons, Inc.

Yaakob Daud (2007). Kedudukan ko-kurikulum di sekolah: Persepsi guru dan pelajar. Fakulti Pendidikan, Universiti Kebangsaan Malaysia: Bangi, Selangor.

Yukl, G. (2002). Leadership in Organizations, 5th ed., Prentice Hall, Upper Saddle River, NJ.

Zaidatol Akmaliah (1990). Pentadbiran Pendidikan. Shah Alam: Penerbitan Fajar Bakti Sdn. Bhd.

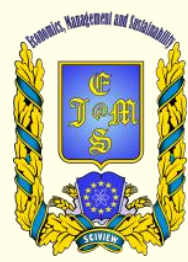

() 2016-2017, Economics, Management and Sustainability. All rights reserved.

This open access article is distributed under a Creative Commons Attribution (CC-BY) 4.0 license.

You are free to:

Share - copy and redistribute the material in any medium or format Adapt - remix, transform, and build upon the material for any

purpose, even commercially.

The licensor cannot revoke these freedoms as long as you follow the license terms.

Under the following terms:

Attribution - You must give appropriate credit, provide a link to the license, and indicate if changes were made.

You may do so in any reasonable manner, but not in any way that suggests the licensor endorses you or your use.

No additional restrictions

You may not apply legal terms or technological measures that legally restrict others from doing anything the license permits.

Economics, Management and Sustainability (ISSN: 2520-6303) is published by Scientific Publishing House "CSR",

Poland, EU and Scientific Publishing House "SciView", Poland

Publishing with JEMS ensures:

- Immediate, universal access to your article on publication

- High visibility and discoverability via the JEMS website

- Rapid publication

- Guaranteed legacy preservation of your article

- Discounts and waivers for authors in developing regions

Submit your manuscript to a JEMS at http://jems.sciview.net or submit.jems@sciview.net

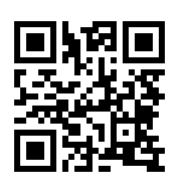

